\title{
PETROGRAPHIC FEATURES AND MODELLING OF SOME WATERFALL ROCKS IN KENYIR LAKE, TERENGGANU: A MICROSCOPIC PERSPECTIVE APPROACH IN SUSTAINABLE GEOTOURISM
}

\section{Muhd Nur Ismail Abdul Rahman' ${ }^{1}$ Ahmad Norzaimie Roslan' ${ }^{2}$, Nor Bakhiah Baharim ${ }^{3}$, Azman Abdul}

Ghani $^{4}$ \& Che Aziz Ali ${ }^{5}$

1,2,3Paleoceanography Research Group (PoRIG), Faculty of Science and Marine Environment,

University Malaysia Terengganu

${ }^{4}$ Geology Department, Faculty of Science, University of Malaya

${ }^{5}$ School of Environmental and Natural Resources, Faculty of Science and Technology,

University Kebangsaan Malaysia

(nur.ismail@umt.edu.my, zaimieroslan91@gmail.com, n.bakhiah@umt.edu.my, azmangeo@um.edu.my, che@ukm.edu.my)

\begin{abstract}
Waterfalls around Kenyir Lake, Terengganu naturally serve as an iconic symbol of amazing rock bounded formation amidst the wilderness, which stores a hidden story for millions of years. The waterfalls feeding the Kenyir Lake have become tourists' main attractions since they are located separately on a different island. There are three naturally picturesque waterfalls worth seeing in the study area, namely Sungai Buweh Waterfall, Lasir Waterfall, and Saok Waterfall, which are made up of granitic rock body that emerged in the Eastern Belt during the Late Triassic ( 251.2 Ma). To date, the waterfall landscape in any area concerned with geotourism focusses more on outcrop architecture and geomorphological features, but has only limited accessibility to rock records. This study was carried out to evaluate the geo heritage features, of the waterfall landscape as well as its rock-forming minerals. Three rock samples were carefully collected from the waterfalls and subsequently prepared for optical thin section petrography analysis using a polarised light microscope. The optical thin section petrography further revealed precise mineral compositions, fabrics, and microstructures. A photomicrograph of the thin sections was also taken at low and high magnification levels in plane polarised light (PPL) and cross polarised light (XPL). Additionally, petrographic modelling was constructed using optical microscopic data to help identify a microscopic mineral (a hidden material in rock) in detail so that the mineral becomes clear to both geologists and the public at large. Generally, this modelling will enlighten the public on the material embedded in the rocks and illustrate the importance of learning about rock-forming minerals as well as to embed the idea of making the waterfall a Sustainable Development Goal (SDG). Besides making geology an interesting field to embark on, this mineral find affirms the beauty of the waterfalls for tourism purposes, thereby connecting geotourism and nature. The minerals from various constituents are also useful for scientific heritage purposes and may benefit the economy by serving as sustainable tourism while being part of a geopark.
\end{abstract}

KEYWORDS: Kenyir Lake, granitic rock, petrography, geology, geotourism

\section{PURPOSE AND BACKGROUND}

Kenyir Lake lies at a latitude of $4^{\circ} 46^{\prime} \mathrm{N}$ and longitude $102^{\circ} 35^{\prime} \mathrm{E}$ and receives water from the main river on the Terengganu River Basin (Suratman et al., 2005). Overall, the lake covers $260 \mathrm{~km}$ and has $340 \mathrm{small}$ islands, limestone caves, and more than 14 waterfalls and small rivers. The topography of Kenyir Lake and 
the surrounding area achieve a maximum elevation of about 1500 meters, and the area is encircled with rugged terrain, mainly at North and South, and has a lower area (i.e., the middle section) completely submersed in water. The catchment area of Kenyir Lake is mainly underlain by felsic igneous rocks of granite and granodiorite, marine clastic rock (shale and sandstone), minor carbonate rocks with some metamorphic rocks (phyllite, quartzite), including basic to intermediate volcanic rocks.

The geological features of the Lake as a tourist attraction and its geo-heritage value have recently been accepted and promoted around the world, thereby allowing it to use the geo-tourism classification and opening up Kenyir Lake as a site for a potential geopark. Geo-tourism has been developed in recent years to minimise the negative impact of mass tourism at tourist sites around geological and geomorphological attractions (Newsome \& Dowling, 2010), geo-tourism primarily emphasises sustainable tourism development in rural and natural environments.

At present, a geopark has been established owing to some of the values discussed above, but it has been more focussed on outcrop architecture and geomorphological features, and has only limited accessibility to the rock records. While the public might be aware of what a "rock," is they may not know how amazing the rock is on the inside; hence, the question is not about its appearance on the surface, but rather the materials and qualities inside of the rock.

In this regard, the current study was carried out to evaluate the geo-heritage features, such as the waterfall landscape and study the rock forming minerals. Ultimately, using an interactive learning platform for interpreting rock-forming minerals and their functions in line with sustainable geo-tourism, this study also aims to educate the public.

\section{METHODOLOGY}

The sampling was conducted by collecting granite rocks from Buweh, Saok, and Lasir waterfalls for petrophysical analysis purposes. As for the petrographic method, to identify significant minerals the authors used the general polished thin section, which was prepared based on King's (1957) procedure.

In this study, the modelling for the petrographic composition section such as quartz along with the various types of feldspar were constructed using integrated software, Autodesk 3ds Max and Debrismaker 2.0 .

\section{FINDINGS}

This study has successfully evaluated the three waterfalls in Kenyir Lake: Buweh Waterfall (BW), Saok Waterfall (SW), and Lasir Waterfall (LW), which is further divided into Lasir Waterfall Left (LWL) and Lasir Waterfall Right (LWR).

Two prominent geological heritage features, namely waterfall landscapes and rock units, have been evaluated and identified within those waterfalls as a significant geological heritage due to their substantial aesthetic and scientific values. Most of the waterfalls exposed in Kenyir Lake encompass horsetail and fan types that are partially in contact with rocks.

As a result of the constant water flow, the rocks are likely to erode faster. While BW and SW can be characterised as an early stage of waterfall development, LWR, however, is more prone to advancing its development. With the study and discussion on petrographic or optical-mineral data for the mineral in a rock, we will, therefore, be enlightened about the exact material in a rock to better understand the landscapes and the geologic history of the area. 
Meanwhile, the modelling and possibleVirtual Reality Device (VRD) are equally discussed as a possible method to educate the public about a significant of minerals present. Quartz, a common major mineral in a granite rock with various feldspar types have been highlighted to represent an iconic education model for educating the public about the wonderful rock-bounded waterfalls. Both quartz and feldspar are from major silicate crystal groups and share the same mineral constituents, leading to similar mineral lattices.

ForVRD, this interactive tool is useful in teaching the public about minerals more easily and realistically without the need to observe the minerals under a microscope.

\section{CONCLUSION}

First, the Buweh Waterfall (BW) encompasses a horsetail type with aesthetic, educational, and scientific values, where the petrographic analysis for microscopic materials in the coarse granite rocks has revealed the abundance of quartz with plagioclase and potassium feldspar; however, plagioclase feldspar was more abundant than potassium feldspar. Next, the Saok Waterfall (SW) similarly encompasses a horsetail type and additionally develops a long canal with several stages, illustrating both aesthetic and scientific values. Lastly, the Lasir Waterfall (LW), which combines both horsetail and fan types, was recognised as the most attractive location among visitors. Modelling has been done on the major minerals (quartz and feldspar) exposed from the polished thin section.

Specifically, the common quartz mineral has been modelled using a combination of crystallographic forms to create a trigonal crystal system. Meanwhile, for feldspar, modelling is available for the major mineral exposed in the polished thin section with a variety of twinning in some feldspar groups, namely albite, microcline, and sanidine.

\section{CONTRIBUTION/PRACTICAL IMPLICATIONS}

Generally, this modelling will enlighten the public on the material embedded in the rocks and illustrate the importance of learning a rock-forming mineral as well as to bring it in line the idea of making Kenyir Lake part of its Sustainable Development Goals (SDG). Besides making geology an interesting field to embark on, this mineral affirms the beautiful scenery of waterfalls for tourism, thereby connecting the interrelationship between geotourism and nature. The minerals from various constituents are also useful for scientific heritage and may benefit the economy by serving as sustainable tourism while being part of a geopark.

\section{ACKNOWLEDGEMENTS}

This study has benefited from the support of Talent and Publication Enhancement Research Grant (TAPERG) 2020 for sponsoring the project. Our gratitude is also extended to Universiti Malaysia Terengganu for all help and moral support towards the publication of this paper.

\section{REFERENCES}

King, G. A. (1957). Technique for thinned polished sections. American Mineralogist, 42(9-10), 689-694.

Newsome, D., \& Dowling, R. K. (2010). Geotourism: The tourism of geology and landscape. Oxford: Goodfelow publishers, Ltd.

Suratman, S., Sailan, M. M., Hee, Y. Y., Bedurus, E. A., \& Latif, M. T. (2005). A preliminary study of water quality index in Terengganu River basin, Malaysia. Sains Malaysiana, 44(1), 67-73. 